\title{
THE PROSPEGTIVE EFFEGTS OF MODIFYING EXISTING LAW TO ACCOMMODATE PREEMPTIVE SELF-DEFENSE BY BATTERED WOMEN
}

\author{
MARTIN E. VEINSREIOERIS ${ }^{\dagger}$
}

\section{INTRODUCTION}

The acceptance of violence between private citizens in a free society, while morally repugnant, is seemingly necessary. The coexistence of laws punishing for murder and absolving absolutely for self-defense points to a tension between values that society holds as sacred. Nowhere is this tension more apparent than in the debate over the concept of "preemptive" self-defense. This particular variant of self-defense arises in situations where a would-be aggressor is attacked without a clear, imminent show of force, based on the wouldbe victim's perception of future danger. ${ }^{1}$ This Comment explores the role of preemptive strikes in the law of self-defense in three contexts: battered woman syndrome cases, prisoner on prisoner violence, and the so-called "cultural defense." In particular, this Comment argues

† B.A. 1998, Duke University; J.D. Candidate 2001, University of Pennsylvania Law School. I give my sincere and loving thanks to my parents Otto and Patricia, and to my sister Erica. I also thank the editors of Volumes 148 and 149 for their hard work.

"In a strict sense, "[s]elf-defensive force is always preemptive." Larry Alexander, $A$ Unified Excuse of Preemptive Self-Protection, 74 NOTRE DAME L. REv. 1475, 1476 (1999). For example, " $A$ draws his pistol and points it threateningly at $B$. $B$ draws his own pistol and fires at $A$. $B$ 's act is one of paradigmatic self-defense. But $A$ had not yet fired at $B$... Had $A$ actually fired all of his bullets before $B$ could draw, $B$ 's subsequent use of force would not be self-defensive but retaliatory." Id. at 1476-77. This Comment, however, focuses on situations where "the best defense may be to attack first, thus blurring the line between aggressor and target." James E. Robertson, "Fight or F..." and Constitutional Liberty: An Inmate's Right to Self-Defense When Targeted by Aggressors, 29 IND. L. REV. 339, 339-40 (1995).

"The "cultural defense" exists as a loosely defined set of theories regarding the role that an immigrant's indigenous culture should play in assessing culpability. One commentator defines the defense by stating that:

A successful cultural defense would permit the reduction (and possible elimination) of a charge, with a concomitant reduction in punishment [based upon the theory that] an individual's behavior is influenced to such a large extent by his or her culture that either (i) the individual simply did not 
that the dilution of self-defense law's imminence requirement in cases in which battered women preemptively attack their husbands will be misappropriated by prisoners, who could claim the right to preemptively attack other inmates. Likewise, proponents of the cultural defense will use a relaxed imminence requirement to argue that preemptive strikes in the name of self-defense inhere in a particular minority culture's norms, and should thus be excused from culpability. Ultimately, a more focused approach towards preserving the imminence requirement is necessary to prevent preemptive selfdefense claims from succeeding in situations (such as prison) in which society is less prepared to accept this kind of violence than it is in those situations involving battered women.

This Comment generally examines situations in which the dilution of the imminence requirement in self-defense law that is seen in battered woman syndrome cases can be misappropriated by prisoners (and commentators) who claim a right to preemptive self-defense in anticipation of a future attack. Part I of this Comment provides an overview of state statutory treatment of the imminence requirement in self-defense and offers paradigmatic examples of the different formulations. Part II examines various proposals to modify substantive self-defense law in reaction to battered woman syndrome cases. Part III discusses the negative effects that any change to the substantive law as a reaction to battered woman syndrome cases would have on preemptive self-defense in prison. Part IV explores the possibility that acts of violent preemptive self-defense could be excused through a combination of a relaxed imminence requirement and the cultural defense. Finally, Part $V$ argues that clemency, encompassing both pardons and commutation of sentences in battered woman syndrome cases, rather than a relaxed imminence requirement with far-reaching negative effects, could serve as an alternative means of pursuing the interests of justice. ${ }^{3}$

believe that his or her actions contravened any laws..., or (ii) the individual was compelled to act the way he or she did....

Alison Dundes Renteln, A Justification of the Cultural Defense as Partial Excuse, 2 S. CAL. REV. L. \& WOMEN'S STUD. 437, 439 (1993).

${ }^{3}$ Any discussion of social issues such as battered woman syndrome, and of women who use violence to defend themselves while not immediately threatened, inevitably includes value judgments based on concepts of both individual and collective morality. As a result, generalization becomes a necessary evil. One would assume that the vast majority of lay citizens would agree that the North Carolina Court of Appeals was correct in the infamous case of State $v$. Norman (Norman I), 366 S.E.2d 586, 592 (N.C. C. App. 1988), rev'd, 378 S.E.2d 8 (N.C. 1989), when it overturned Judy Norman's conviction for killing her abusive husband while he slept. Likewise, not only lay 


\section{THE ROLE OF IMMINENCE IN SELF-DEFENSE LAW}

The basic requirements for the use of force to defend oneself against an unlawful attack are generally well settled, yet they are riddled with small differences from jurisdiction to jurisdiction. One may use force to defend oneself so long as the responsive force is necessary, in response to an imminent attack, and proportional to the force threatened." These three basic doctrinal requirements have been composed in seemingly infinite linguistic variations.

\section{A. Model Penal Code}

The Model Penal Code, for example, states that "the use of force upon or toward another person is justifiable when the actor believes that such force is immediately necessary for the purpose of protecting himself against the use of unlawful force... on the present occasion." The Model Penal Code also allows the use of deadly force if the actor "believes that such force is necessary to protect himself against death, serious bodily injury, kidnapping or sexual intercourse compelled by force or threat."

citizens, but many commentators would agree that the North Carolina Supreme Court was legally and morally wrong to overturn the Court of Appeals and reinstate Norman's conviction in State v. Norman (Norman II), 378 S.E.2d 8 (N.C. 1989). Therefore, a certain amount of social (if not legal) acceptance for the actions of battered women is assumed. As one commentator noted:

On one level the view of the majority of the North Carolina Supreme Court is unassailable-the threat of death or great bodily harm was not imminent when Ms. Norman shot her husband, not, at least, by any reasonable interpretation of the word imminent... Thus, to the extent the court was simply applying the settled law of North Carolina, its decision was surely correct....

At a deeper level, however, the decision is disturbing. ...

If it is true, as the evidence at trial tended to show, that either a call to the police or an attempt to run away would have resulted in a risk of death or further torture, then is it proper for society to brand Ms. Norman, and others similarly situated, as criminals?

Richard A. Rosen, On Self-Defense, Imminence, and Women Who Kill Their Batterers, 71 N.C. L. REv. 371, 375-76 (1993) (footnotes omitted); see also infra note 73 and accompanying text (discussing the comparative morality of preemptively killing an abusive spouse and killing a prison inmate to gain status).

${ }^{4}$ WAYNE R. LAFAVE \& AUSTIN W. SCOTT, SUBSTANTTVE CRIMINAL LAW $\$ 5.7$ (1986); see also Alexander, supra note 1, at 1476 (providing theoretical bases for self-defense law).

Model Penal CoDE $\$ 3.04$ (1) (1962).

"Id. $\$ 3.04(2)$ (b). The Model Penal Code's allowance of deadly force against sexual intercourse compelled by force or threat is particularly significant when considering both preemptive strikes in the prison context and battered woman 
seemingly broader allowance of force against such crimes is "the extreme degree to which [such crimes] deprive the victims of the opportunity to exercise their right to self-determination." example of self-defense that might be justified under the Model Penal Code, but not under certain state statutory schemes, is:

$V$ takes a book to a bench in the park, fully intending to sit there and read all afternoon; $A$ approaches with a baseball bat, orders $V$ to stay on the bench until 3:00 P.M., and threatens to hit $V$ with the bat if but only if $V$ tries to leave before 3:00. When noise distracts $A, V$ makes her escape by grabbing the bat and hitting $A$, breaking his leg.

Under the Code's liberty-enhancing scheme, such a use of force is legitimate because $V$ s "sovereignty" is threatened.

\section{B. State Statutory Treatment}

State statutes generally treat the immediacy requirement of selfdefense in one of two ways. Certain statutes use language stating that any threatened force must be "imminent" before self-defense is allowed. ${ }^{10}$ Other statutes use language indicating that any force used must be "immediately necessary." As will be evident when considering battered woman syndrome and prisoner self-defense, the specific formulations have inherent differences and can sometimes have an effect on whether or not a jury instruction is given on selfdefense. ${ }^{12}$

syndrome cases. Certain states also explicitly allow for the use of deadly force to prevent sexual intercourse compelled by force. See, e.g., ALA. CODE $§ 13 A-3-23$ (a) (3) (1975) (allowing the use of deadly force to prevent "forcible rape or forcible sodomy"); COLO. REV. STAT. $\$ 18-1-704$ (2) (c) (1999) (allowing deadly force when "[t]he other person is committing or reasonably appears about to commit ... sexual assault").

${ }^{7}$ ROBERT F. SCHOPP, JUSTIFICATION DEFENSES AND JUST CONVICTIONS 86 (1998).

${ }^{8} I d$. at 63 (footnote omitted).

${ }^{9} I d$.

${ }^{10}$ See, e.g., ALA. CODE $\$ 13 A-3-23$ (a) (1975) (justifying the use of physical force when faced with the imminent, unlawful force of another); COLO. REV. STAT. \$ 18-1704(1) (1999) (same); GA. CODE ANN. § 16-3-21 (a) (1999) (same); KAN. STAT. ANN. \$ 21-3211 (1995) (same); OR. REV. STAT. \$ 161.209 (1990) (same).

${ }_{11}$ See, e.g., ARIZ. REV. STAT. \$ 13-404(A) (1989) (justifying the use of physical force when it is immediately necessary to protect oneself from the unlawful force of another); DEL. CODE ANN. tit. 11, § 464(a) (1975) (same); HAW. REV. STAT. $\$ 703-$ 304(1) (1993) (same); 18 PA. CoNs. STAT. ANN. \$ 505(a) (West 1998) (same).

${ }^{12}$ See infra Part II.B.1 (discussing the impact of a choice between "imminent" and "immediately necessary"). Not all commentators see the distinction between the two formulations as significant. See SCHOPP, supra note 7, at 99 ("[A]lthough some courts and commentators have attributed significance to the selection of 'imminent' or 
Alongside the distinction between "imminent" and "immediately necessary" is the requirement of reasonableness found in certain state statutes. $^{13}$ The presence of a reasonableness requirement indicates that the jurisdiction has an objective standard of self-defense, while the lack of such a requirement generally indicates a subjective standard of self-defense. ${ }^{14}$ Again, the presence or lack of a reasonableness requirement is clearly relevant to the actions of battered women and to those of prisoners who attack preemptively out of self-defense. ${ }^{15}$ In fact, the reasonableness requirement often serves as a gatekeeper for a self-defense instruction to a jury. ${ }^{16}$

An example of a state that has adopted a broad approach to its statute's imminence and reasonableness requirements is North Dakota. That state's supreme court stated in the case of State $v$. Leidholm, which involved a woman killing her husband while he slept after an argument:

If, therefore, a person has an actual and reasonable belief that force is necessary to protect himself against danger of imminent unlawful harm, his conduct is justified or excused....

$[W]$ e now decide that the finder of fact must view the circumstances attending an accused's use of force from the standpoint of the accused to determine if they are sufficient to create in the accused's mind an honest and reasonable belief that the use of force is necessary to protect himself from imminent harm. ${ }^{17}$

In many cases involving battered women, as will be seen, the immediacy requirement can often be more outcome-determinative

'immediate,' neither ordinary nor legal usage supports this attribution when the two terms are accurately interpreted.").

is See, e.g., N.Y. PENAL LAW $\$ 35.15$ (1) (McKinney 1997) (“A person may... use physical force upon another person when and to the extent he reasonably believes such to be necessary to defend himself or a third person from what he reasonably believes to be the use or imminent use of unlawful physical force by such other person ....").

${ }^{14}$ See People v. Goetz, 497 N.E.2d 41, 49-50 (N.Y. 1986) (discussing the difference between subjective and objective jurisdictions and comparing New York's objective standard to the Model Penal Code's subjective standard).

${ }_{15}$ See infra Part III (discussing the potential misappropriation of self-defense law by prison inmates).

${ }^{16}$ See Holly Maguigan, Battered Women and Self-Defense: Myths and Misconceptions in Cunent Reform Proposals, 140 U. PA. L. REV. 379, 412 (1991) ("A reasonableness standard's outcome-determinative impact on the content of a self-defense instruction is obvious.").

${ }^{17}$ State v. Leidholm, 334 N.W.2d 811,816-18 (N.D. 1983) (citations omitted). 
than a reasonableness judgment. ${ }^{18}$

\section{SELF-DEFENSE AND BATTERED WOMAN SYNDROME}

\section{A. The Role of Battered Woman Syndrome in the Courtroom}

The origin of battered woman syndrome is typically traced back to the 1979 book The Battered Woman by Lenore Walker. ${ }^{19}$ Walker's theories have become quite well known and well commented upon in both legal and sociological circles. ${ }^{20}$ Battered woman syndrome is usually introduced to a jury through expert testimony. ${ }^{21}$ As a practical matter, courts increasingly have accepted expert testimony regarding battered woman syndrome since its initial formulation, particularly in cases involving homicides. ${ }^{22}$ The utility of battered woman syndrome testimony for the defense is summarized by Robert Schopp:

Courts and commentators have argued that expert testimony regarding battered woman syndrome provides juries with important information regarding several aspects of self-defense.... [S] ome cases involve circumstances in which the defendants exercise violence in the absence of an imminent overt attack. Some contend that expert testimony regarding the syndrome explains how these defendants could reasonably believe that attacks were forthcoming and that defensive force was necessary despite the absence of immediate violence. Some courts and commentators discuss a special ability to perceive subtle clues of

${ }^{18}$ See Maguigan, supra note 16, at 413 (explaining that reasonableness "is not the sole determinant ... [but rather] the more significant impact is from the jurisdiction's definition of the temporal proximity of danger").

${ }^{19}$ See David L. Faigman \& Amy J. Wright, The Battered Woman Syndrome in the Age of Science, 39 ARIZ. L. REV, 67, 68 (1997) (stating that Walker's book introduced the first working hypothesis of battered woman syndrome).

${ }^{20}$ Walker's theories, while widely used in the courtroom, have very vocal critics. See, e.g., ia. at 75-78 (arguing that Walker's cycle theory suffers from "empirical vacuity"); see also Shelby A.D. Moore, Battered Woman Syndrome: Selling the Shadow to Support the Substance, 38 How. L.J. 297, 301 (1995) (arguing that battered woman syndrome reinforces "debasing female stereotyp[es]").

${ }^{21}$ Admissibility is, of course, the first threshold regarding expert testimony. See FED. R. EVID. 702 (permitting expert testimony to assist the trier of fact in understanding evidence and facts in issue). More importantly, however, courts vary significantly from state to state in determining the scope and purpose of expert testimony regarding battered woman syndrome. See Maguigan, supra note 16, at 429-30 (noting that certain states allow only a general description of the syndrome by an expert, while other states allow an expert to give an opinion as to whether the defendant's actions against her batterer were reasonable).

${ }^{22}$ See Faigman \& Wright, supra note 19, at 81 (noting that "[i]n general, courts have been sympathetic toward defendants' use of the battered woman syndrome in homicide prosecutions, and most admit expert testimony concerning this issue"). 
forthcoming violence as part of the syndrome, arguing that this aspect of the syndrome renders the perception of ${ }_{23}$ minent violence reasonable despite the lack of external indicators....

The acceptance of battered woman syndrome testimony in the courtroom is far from universal; as Faigman and Wright note, "this sympathetic approach has not been entirely uncritical and some courts remain adamantly opposed to the introduction of this evidence on the basis of legal doctrine or inadequate science." ${ }^{24}$ While the introduction of past instances of abuse and of expert testimony regarding the reasonableness of a particular woman's response to abuse does not guarantee an acquittal, expert testimony affords defendants the opportunity to prove an affirmative defense.

The model introduced by Walker includes a series of cycles, whereby a "tension building" phase is followed by an "acute battering incident," which is in turn followed by a period of "loving contrition." During the phase of "loving contrition," the batterer "typically expresses regret and profusely apologizes, usually promising never to batter the woman again," which contributes to the victim staying in the abusive relationship. ${ }^{26}$ During the cycle, the woman falls victim to a "cumulative terror" of violence, fearing harm "even during the peaceful interlude between episodes of abuse." ${ }^{27}$ As a result, the victim often sees a lull in the violence as her only opportunity to defend herself against a physically larger and stronger aggressor, and against the looming threat of future violence. ${ }^{28}$

More significant than expert testimony regarding reasonableness in such cases is the difference in practical application between

${ }^{23}$ SCHOPP, supra note 7, at 93.

${ }^{24}$ Faigman \& Wright, supra note 19, at 81 (citation omitted). This concern about inadequate science is shared by many commentators. See, e.g., Stephen J. Morse, The "New Syndrame Excuse Syndrame," 14 CRIM. JUST. ETHICS 3, 4 (1995) ("All too often ... the new syndromes are not sufficiently validated and are the product of unacceptably 'soft' science or clinical crockery."); see also Hill v. State, 507 So. 2d 554, 555 (Ala. Crim. App. 1986) (holding that "[ $t]$ he danger of a jury's according undue weight to unproven and perhaps unreliable scientific testimony justifies excluding such evidence"); State v. Necaise, 466 So. 2d 660, 665 (La. Ct. App. 1985) (rejecting expert testimony regarding battered woman syndrome as legally similar to allowing a claim of "partial responsibility," an approach that had been rejected in favor of an "all or nothing' (i.e., sane or insane) approach" in Louisiana).

25. Faigman \& Wright, supra note 19 , at 72 (quoting Lenore E. Walker, THE BATTERED WOMAN SYNDROME 95-104 (1984)).

id. Id.

Id. at 73 .

" See id. (describing these features of the cycle); see also infra notes $38-40$ and accompanying text (discussing obstacles to leaving an abusive situation). 
reasonableness and imminence. As was seen in Norman II, imminence is often a greater hurdle than is reasonableness for acquittal in battered woman syndrome cases. Many judges and juries will accept a preemptive attack on a batterer as intrinsically "reasonable," but then have a difficult time explaining away the attack's circumstances. ${ }^{29}$ While imminence and reasonableness are interrelated, for the purposes of certain instances of self-defense, they can be broken down into separate, independent components. This has led commentators to search for alternatives to the imminence rule-alternatives which would prove troublesome if applied to similar circumstances outside the context of spousal abuse.

\section{B. Formulations of Preemptive Self-Defense in Cases Involving Battered Women}

One of the most controversial areas of legal scholarship and practice involving battered women involves cases in which a victim attacks her batterer without immediate provocation. ${ }^{30}$ While it is unclear how prevalent these cases are, they are sensational enough that commentators and courts have seized upon them as mediums for debate regarding the true substance of self-defense law. ${ }^{31}$

${ }^{29}$ The North Carolina Supreme Court, in overturning the court of appeals, recognized this tension by referring to the defendant's evidence in the case as "poignant" but holding nonetheless that the defendant was not in imminent fear of death when she killed her husband. State v. Norman (Norman II), 378 S.E.2d 8, 15 (N.C. 1989). One might presume that if the court applied a strict test of reasonableness without considering imminence, the result of the case might have been different.

Soe, e.g., State v. Stewart, 763 P.2d 572, 57476 (Kan. 1988) (describing facts where defendant shot her husband while he slept); State v. Norman (Norman I), 366 S.E.2d 586, 587-89 (N.C. Ct. App. 1988) (describing circumstances leading to the killing and noting that the defendant shot her husband while he slept). As was the case with the North Carolina Supreme Court in Norman II, in Stewart, the Kansas Supreme Court held that the shooting could not be self-defense due to a lack of imminent danger. See Stewart, 763 P.2d at 579 (holding that "when a battered woman kills her sleeping spouse when there is no imminent danger... a self-defense instruction may not be given").

${ }^{31}$ The actual prevalence of cases involving nonconfrontational attacks is a point of debate. See Maguigan, supra note 16, at 384 (arguing that "over seventy percent of all battered women who kill do so when faced with either an ongoing attack or the imminent threat of death or serious bodily injury"). Maguigan also describes nonconfrontational killings as a popular myth. See id. at 388-401 (arguing that appellate opinions and empirical evidence from social scientists indicate that legal scholars are incorrect in assuming most battered women kill during nonconfrontational situations). But see Rosen, supra note 3, at 403-04 \& n.84 
The most significant problem with cases where battered women attack their husbands in nonimminent situations is that, despite the fact that their actions do not fit the neat definition of self-defense, an innate sense of justice nevertheless leads judges, juries, and legal commentators to blur the edges of self-defense law in order to defend the women's actions. As this Comment seeks to show, such subtle manipulation and change of the substantive law of self-defense, while possibly desirable to achieve just results in this narrow context, inevitably will lead to undesirable results in other contexts. ${ }^{32}$ Stephen Morse outlines the changes to substantive law desired by some advocates by stating that "[c]ourts and, less often, legislatures are increasingly inundated with claims that syndromes old and new... should be the basis for... legal change.... [One] proposal is the expansion of old defenses: for example, loosening objective standards for justifications such as self-defense. ${ }^{, 33}$ The imminence requirement is often the starting point for those who seek to change the law in such a manner.

\section{Eliminating the Standard of Imminence}

The first proposal offered regarding nonconfrontational situations in which a battered woman kills her abuser is a reformulation of the substantive definition of self-defense without an imminence requirement. ${ }^{34}$ The obvious problem with eliminating the requirement is that something must stand in its stead to distinguish between legitimate and illegitimate uses of self-defense. ${ }^{35}$ One proposal seeks to replace the imminence requirement with a more adaptable standard of necessity:

[T] he traditional insistence on a literally "imminent" infliction of great

(criticizing Maguigan's assertion that nonconfrontational killings are isolated incidents).

${ }_{* 3}^{*}$ See infra Part III (discussing preemptive self-defense in prison).

${ }^{3 x}$ Morse, supra note 24 , at 3.

${ }^{34}$ See Stephen J. Schulhofer, The Gender Question in Criminal Law, 7 Soc. PHIL. \& POL'Y 105, 127 (1990) (arguing that the distinctive features of battering situations render the imminence requirement irrelevant); see also Sarah Baseden Vandenbraak, Note, Limits on the Use of Defensize Force to Prevent Intramarital Assaults, 10 RUTGERS-CAM. L.J. 643, 658 (1979) (arguing that imminence should not be a necessary component of self-defense).

33 Imminence serves as a threshold requirement for legitimate uses of self-defense: "[I]n most circumstances the judgment that no nonviolent alternative will suffice is more likely to be accurate regarding an imminent harm than a remote one." SCHOPP, supra note 7, at 102. 
bodily harm must be abandoned outright. Imminence is relevant only because it helps identify cases where flight or legal intervention will be impossible, so that violent self-help becomes truly necessary. The decisive factor is necessity, not imminence per se. ${ }^{36}$

The justification for abandoning the imminence requirement is often put simply in terms of justice:

Courts' refusal to recognize a right of self-defense in a nonconfrontational situation, such as when the battered woman kills her batterer while he sleeps, by creating a per se rule that the threatened harm be "imminent" before a self-defense instruction may be given to a jury, may be unjust in a battered woman's situation. ${ }^{37}$

Such a standard could benefit defendants in cases such as Norman II, but it proves to be problematic. First, if the traditional justification of necessity replaces the imminence requirement, a typical battered spouse may not be exculpated in every case. The necessity defense provides that "there must have been no adequate alternative" to the act. ${ }^{38}$ Yet a defendant in a nonconfrontational killing has the option to escape harm by the very definition of the encounter. In other words, if the batterer is sleeping, the adequate and reasonable alternative to attacking him is simply to leave the situation. However, the woman in the relationship typically has been threatened with either great bodily harm or death if she leaves; therefore, no reasonable alternative exists. ${ }^{39}$ This lack of alternatives is amplified by social pressures, including a lack of financial resources, family support, or child care concerns, as well as psychological pressures, including "learned helplessness ... rendering the defendant unable to leave by preventing her from recognizing and taking advantage of available opportunities to alter her situation."

A stronger critique of using a necessity standard in battered woman syndrome cases is that the traditional definition of necessity

${ }^{36}$ Schulhofer, supra note 34 , at 127.

${ }^{37}$ M.J. Willoughby, Comment, Rendering Each Woman Her Due: Can a Battered Woman Claim Self-Defense When She Kills Her Sleeping Batterer?, 38 U. KAN. L. REV. 169, 191 (1989).

${ }_{39}$ Nelson v. State, 597 P.2d 977, 979 (Alaska 1979).

${ }^{39}$ See Martha R. Mahoney, Legal Images of Battered Women: Redefining the Issue of Separation, 90 MiCH. L. REV. 1, 83-93 (1991) (discussing the problem of "separation assault" and describing the underlying threats made against women who eventually kill their abusers); see also infra Part II.B.3 (discussing a proposal that would take a battered woman's alternatives into account in deciding whether to grant a self-defense instruction without an imminence requirement).

${ }^{40}$ ScHOPP, supra note 7, at 112. 
typically does not allow for homicide on the theory that the harm caused would be greater than the harm avoided. ${ }^{41}$ As a byproduct, the law of necessity is in conflict with the Model Penal Code, as well as state statutes that allow for deadly force to prevent forcible sexual intercourse, which is often a component of battered woman syndrome. The Model Penal Code addresses this dichotomy by stating that "[w] hile there may be situations, such as rape, where it is hardly possible to claim that greater evil was avoided than that sought to be prevented by the law defining the offense, this is a matter that is safely left to the determination and elaboration of the courts., ${ }^{* 2}$ In essence, proponents of replacing the imminence requirement with the principle of necessity offer a solution that by definition is unworkable because it will excuse homicide only infrequently. ${ }^{43}$ Given the definitions of the Model Penal Code and state statutes, replacing imminence with necessity is logically unsound, and would not achieve the desired result because the harm of homicide would be greater than the harm avoided in most cases.

An alternative to replacing the imminence requirement with the justification of necessity is switching from imminence to the "immediately necessary" standard, or the Model Penal Code's formulation." The obvious problem with this proposal is that, removed from the issue of reasonableness, there is little practical difference between the two standards. ${ }^{45}$ In addition, the elimination of imminence and the implementation of the "immediately necessary" standard does not mean that a jury will always ignore imminence in a battered woman case. On the contrary, "[e]liminating the imminence requirement in a specific case does not mandate a specific verdict. ... Nor does its elimination make the question of imminence irrelevant. Imminence remains, as do the other factors in the case, relevant to

11 Nelson, 597 P.2d at 979.

4Z MODEL PENAL CODE, $\$ 3.02$ cmt. 3 (1962) (citation omitted); see also supra note 6 (providing examples of states that allow for deadly force in this context).

4 See generally JOSHUA DRESSLER, CASES AND MATERLALS ON CRIMINAL LAW 488-93 (1994) (discussing necessity as a defense to murder, as well as the Dudley $\mathcal{E}$ Stephens case).

"Schulhofer, supra note 34, at 127-28; see also supra notes $10-15$ and accompanying text (citing various statutory uses of the terms "imminent" and "immediately necessary," while noting that some argue the distinction between the two terms is not significant).

${ }^{45}$ See Rosen, supra note 3, at $377 \mathrm{n} .11$ (noting that although Schulhofer advocates the "immediately necessary" standard, he fails to explain the actual difference between "imminent" and "immediately necessary"). 
the jury's core inquiry." Additionally, one commentator's empirical research suggests that a switch from "imminent" to "immediately necessary" could actually hurt a battered woman's chances of prevailing on a theory of self-defense. As she concludes from a state survey, "[a] battered woman defendant in an 'imminent' jurisdiction is more likely than her counterpart in an 'immediate' jurisdiction to get a jury instruction specifically on the relevance of the decedent's past violence." The issue of past violence is, of course, of utmost importance to a woman who kills her sleeping batterer; the batterer's past actions will often shape a jury's judgment even when admitted for the sole purpose of determining the defendant's state of mind.

The elimination of the imminence requirement, while superficially appealing to those who believe imminence is the sole hurdle to justice for battered women, is not a feasible alternative, and would be undesirable in situations other than battered women's cases. ${ }^{48}$ As the Norman II court noted:

[C] hanging the "imminent death or great bodily harm" requirement ... would weaken our assurances that justification for the taking of human life remains firmly rooted in real or apparent necessity. That result in principle could not be limited to a few cases decided on evidence as poignant as this.... [T] he relaxed requirements of self-defense found in what is often called the "battered woman's defense" could be extended in principle to any type of case in which a defendant testified that he or she subjectively believed that killing was necessary and proportionate to any perceived threat. ${ }^{49}$

46 Id. at 392.

${ }^{47}$ Maguigan, supra note 16, at 415; see id. at 464-67 (providing surveys indicating decedents' history of abuse, the admissibility of expert testimony and assessments of the reasonableness standard, the temporal proximity of the danger, and the required showings for a self-defense instruction). Maguigan also notes that " $[t]$ he choice of definition, by itself, is a significant indicator of the importance of the social context of a defendant's action." Id. at 414. Maguigan appears to be taking the opposite stance from Schulhofer, arguing that an "imminence" standard expands the temporal circumstances that a jury can consider, while an "immediate" standard restricts those circumstances. See id. (finding that a jury in an "imminence" standard jurisdiction will be required to consider the totality of the circumstances surrounding the defendant's action while the jury in an "immediacy" standard jurisdiction must limit its consideration to the particular instant of the defendant's action); Schulhofer, supra note 34, at 127 (arguing that imminence is relevant only to help identify cases in which flight or legal intervention are impossible, and is therefore not a decisive factor in assessing the likelihood of suffering great bodily harm).

${ }^{48}$ See infra Part III (discussing preemptive self-defense in prison).

49 Norman II, 378 S.E.2d at 15-16 (emphasis added). 


\section{Expanding the Definition of Imminence}

A second proposal to eliminate injustice in cases in which battered women preemptively attack their abusers is an extension of the definition of imminence within the traditional self-defense framework. Specifically, the proposal would make the imminence standard a more subjective one, thereby equating repeated acts of violence against a particular battered woman with a situation in which the defendant is in a perpetual state of imminent danger (or at least fearful) of serious bodily harm or death. ${ }^{50}$ One commentator describes a situation in which a "woman was in a state of cumulative terror because her husband continually threatened to kill her. The past behavior of the husband indicated that he was not bluffing, but was perfectly capable of carrying out his threat." ${ }^{51}$ This notion of cumulative terror would therefore expand the definition of imminence to include the concept of perpetual imminence in the cases of battered women, but otherwise would still be faithful to the traditional definition of self-defense. ${ }^{52}$

The problem with such an expansion is that it allows too much subjectivity, and permits almost any defendant to claim that she was in constant fear of harm, especially in situations like prison, where violence is commonplace. ${ }^{53}$ Therefore, a defendant in a violent environment would be able to take advantage of the violent nature of that environment by arguing that his violent act was a response to constant fear. That constant fear in turn creates an immediate threat and justifies preemptive self-defense. This is an unintentional but inevitable result of allowing this type of expansion.

One proponent of such an expansion of imminence recognizes the possible problems with this proposal when she notes that "[s]ome

See Loraine Patricia Eber, The Battered ITife's Dilemma: To Kill or to Be Killed, 32 HASTINGS L.J. 895, 928-29 (1981) (arguing that the threat in cases of battered women killing their abusers is always imminent); see also CHARLES PATRICK EWTNG, BATTERED WOMEN WHO KILI: PSYCHOLOGICAL SELF-DEFENSE AS LEGAL JUSTIFICATION 59 (1987) (criticizing current self-defense law and the insistence on retaining traditional definitions of imminence in battered woman cases).

Eber, supra note 50, at 929.

52. See id. at 927 (providing a hypothetical situation in which a woman is left by her abusive husband, but he continues to threaten to kill her, and when she sees her husband outside her apartment building she shoots and kills him). Eber states that using the expanded definition of imminence, "an argument can be made that the facts of the hypothetical fulfill the immediacy requirement of self-defense." Id. at 928-29.

s. See infra Part III.B.2 (discussing the environment of constant fear that a prisoner who uses a preemptive strike could use to his advantage at trial). 
commentators have predicted that [such an analysis] will lead to "open season on men." 54 This assumption is rightfully rebutted, though, by stating that " $[t]$ hese women are only killing their husbands because they realize that there is no other way to end the abuse. Battered women are not likely to kill motivated by the assumption that they will be able to get away with it." ${ }^{55}$ In other contexts-such as prison-however, there are very possibly those who are likely to kill motivated by the assumption that they will get away with it. This is the danger of stating that one who is under constant fear of harm is under an imminent threat-there are those who are not killing to escape a dangerous situation, but will misappropriate this expanded definition for less socially justified means.

\section{A Procedural Proposal and Availability of Alternatives}

Richard Rosen offers a third proposal, reacting to the Norman cases in the North Carolina courts. He considers the various responses to self-defense in battered woman syndrome cases and suggests:

[T] he trial judge could instruct the jury that a killing in self-defense must be in response to an imminent danger unless the defendant is able to meet an initial burden of production by presenting substantial evidence that the killing was necessary even though the danger was not imminent. If, and only if, the defendant meets this burden of production would imminence be eliminated as a sine qua non for selfdefense. Only then would the jury be instructed solely on necessity, with the imminence of the threat constituting only one factor among many to be considered. ${ }^{56}$

Rosen also argues that, alongside considerations of imminence and necessity, the jury must take into account the alternatives available to a woman who chooses to commit a nonconfrontational killing. ${ }^{57}$ Essentially, Rosen proposes a burden-shifting procedure that incorporates the previous proposals to eliminate imminence, but only if a defendant meets a "substantial" evidentiary threshold regarding necessity. After the burden-shifting procedure is complete, the issue

${ }^{54}$ Eber, supra note 50, at 930 .

${ }^{55}$ Id. at $930-31$.

${ }^{56}$ Rosen, supra note 3, at 405-06.

57 See id. at 407 (" $[\mathrm{I}] \mathrm{n}$ a case involving a nonconfrontational killing ... evidence about whether she had a realistic chance to avoid death or serious physical abuse without killing ... and whether society had provided her with information about these alternatives, is indisputably relevant."). 
of availability of alternatives should then be addressed.

Rosen's proposal has the virtue of recognizing the dangers of complete elimination of the imminence requirement, but fails to recognize potential abuse of self-defense law. ${ }^{58}$ One of the assumptions inherent to Rosen's theory is that battered woman syndrome cases are the only scenarios in which a defendant who uses preemptive self-defense can claim that she had no reasonable alternative:

In nonconfrontational situations outside of the battered woman scenario, society usually provides other reasonably feasible alternatives to homicidal self-help. Thus, even though the changes in self defense law ... are not limited theoretically to cases in which women kill their batterers, few defendants in generic self-defense cases could meet even a minimal burden of production on a claim that self-defense was warranted even though the danger threatened was not imminent.

As this Comment seeks to show, many inmates who wish to misappropriate preemptive self-defense and attack other inmates will be able to color a plausible claim, whether true or not, that they had no reasonable alternative but to attack first. ${ }^{60}$ Therefore, Rosen's assumption that battered woman syndrome cases have unique factual qualities that preclude the use of preemptive self-defense in other situations is somewhat shortsighted. Additionally, Rosen does not specify the burden of production necessary to avoid an instruction that includes imminence, stating only that it is "substantial." substantial a burden, however, would nullify the reason for the proposed change, as it would prevent the "degree of individual justice" that Rosen states he seeks in battered woman syndrome cases. ${ }^{62}$ Nevertheless, Rosen's proposal does not have as many pitfalls as either eliminating the imminence requirement or changing the definition of imminence.

The various proposals to modify self-defense in the context of battered woman syndrome are problematic by themselves, but become even more so when their prospective effects are considered. While

${ }^{5 *}$ See id. at $391-92$ (discussing possible results of eliminating the imminence requirement).

I9. at 406 .

bee infra Part III.B.1 (discussing the claim that prisoners have no other recourse but to attack first).

61 See Rosen, supra note 3, at 405 (articulating jury instructions that embody the modified imminence and necessity considerations).

Id. at 406. 
these proposals are motivated by a sense of justice, they fail to recognize contexts other than battered woman syndrome in which any new standard of self-defense could be misappropriated as a result of less-than-legitimate motives. Prisons are one such environment where this misappropriation is likely to occur.

\section{PReEmPtive SeLf-Defense IN THE PRISON CoNTEXT}

\section{A. The Role of Violence Within Prison Walls}

Violence in prisons is described as "epidemic" and "ubiquitous." 63 The murder rate in prison has been calculated to be eight times greater than that of the outside world, and the assault rate has been estimated at approximately twenty times that outside prison. ${ }^{64}$ Likewise, "[i]n United States' correctional institutions, instances of sexual violence occur at a staggering rate." ${ }^{95}$ One writer notes that "[s]ome researchers estimate that of the forty-six million Americans who will enter the criminal justice system at some point in their lives, ten million will be raped while in custody."

The effect of this culture of violence that has developed within prison walls is an underground code that places a high value on selfpreservation. ${ }^{67}$ Once within a prison, "retreating in the face of danger is neither normative nor feasible; in prison your back is always against the wall." Alongside the common scenario of two prisoners engaging in mutual combat, however, there exists a separate, almost equally common scenario: in order to protect himself from a vague perception of future harm, one inmate attacks another without provocation and claims self-defense. ${ }^{69}$ These acts are often motivated

${ }^{63}$ Anders Kaye, Comment, Dangerous Places: The Right to Self-Defense in Prison and Prison Conditions Jurisprudence, 63 U. CHI. L. REV. 693, 695-96 (1996).

${ }^{64} I d$. at 696.

${ }^{65}$ Richard D. Vetstein, Note, Rape and AIDS in Prison: On a Collision Course to a New Death Penalty, 30 SUFFOLK U. L. REV. 863, 863 (1997).

${ }^{66} I d$.

${ }^{67}$ See infra text accompanying notes 75-76 (discussing the importance of status and violence in prisons).

${ }_{69}^{68}$ Robertson, supra note 1, at 339 (footnote omitted).

${ }^{69}$ See id. at 340 (noting an inmate's suggestion that "the first time [a potential aggressor] says something to you or looks wrong at you .... walk right up to him and bash his face in and keep bashing him till he's down and out, and yell loud and clear for all the other cons to hear you" (quoting PIRI THOMAS, DOWN THESE MEAN STREETS, 256 (1967))); see also HANS TOCH, LIVING IN PRISON 207-08 (American Psychological Ass'n 1992) (1977) (discussing the use of violence as a preemptive 
by personal interest rather than genuine danger. One author recounts a situation in which an inmate was counseled by a guard to "[p]ick up the nearest thing around you and hit [another inmate] in the head with it. He won't bother you no more." ${ }^{70}$ After this statement the inmate states he will not be locked up for his actions "[b]ecause I am using self-defense."

Although a certain level of violence within prisons is inevitable barring radical reforms, ${ }^{72}$ society faces a line-drawing problem when considering the role of self-defense in prison. For example, society might be prepared to allow a prisoner to use force to defend himself in the face of clear and present danger, but unwilling to accept the situation described above as a legitimate, socially justified use of selfdefense. $^{73}$ This issue complicates any proposals to reform substantive self-defense law stemming from battered woman syndrome cases. Any change in the imminence requirement to address battered woman syndrome cases simply could be misappropriated by a prisoner as a legal justification for a morally questionable action. Additionally, any statute stating that the provisions of the new law would not apply to prisoners would be vulnerable to colorable constitutional due process challenges. $^{74}$

response to threats, and noting that even prison guards sometimes advocate such action to prisoners).

"i) DANIEl Lockwood, Prison SeXual Violence 55-56 (1980) (internal quotation marks omitted).

${ }^{71} \mathrm{Id}$.

72 See Kaye, supra note 63, at 695 (arguing that "nowhere is the need to defend against violence more pressing than amidst the pervasive violence and sparse protections of the modern American prison").

${ }^{7 *}$ Such an assertion contains an implicit moral judgment similar to that made in the battered woman syndrome context. See supra note 3 (discussing the probable reaction to the use of preemptive violence by severely battered women). Certainly, there are those who would disagree with the assertion that preemptive strikes in the name of self-defense by prisoners provide little (if any) social value when compared with the plight of an abused woman. See generally Kaye, supra note 63, at 724-26 (arguing for a constitutional due process right to self-defense for prisoners). Such a judgment, however, is appropriate when considering the implications of legally condoned violence.

[T] he law itself can provide illuminating points of reference for moral evaluation of illegal violence.... [T] he ordinary rules governing use of physical force on behalf of oneself and others reflect a range of implicit moral judgments concerning the kinds of rights or interests that warrant protection by violent acts and the circumstances in which such acts are appropriate.

R. Kent Greenawalt, Vialence-Legal Justification and Moral Appraisal, 32 EMORY L.J. 437, 437 (1983).

${ }^{74}$ See, e.g., Kaye, supra note 63, at 718-24 (arguing in favor of a due process right to self-defense for inmates). Jason Pepe has noted, however: 
While true self-defense is often necessary in prison, allowing preemptive strikes through a lessened imminence requirement is simply not a desirable result. The inevitable effect is that certain prisoners will use violence to increase their stature among their peers in an environment where violence equals respect. ${ }^{75}$ To be accorded status in prison, and 'to be a 'standup guy'-requires one to embrace intimidation and violence as operative principles of everyday life." ${ }^{76}$ If an inmate is able to have a status-enhancing use of violence excused by the courts, the atmosphere of the "walled battlefield" become more violent and lawless than it already is. Allowing preemptive self-defense as a legitimate use of force within prisons will serve to expand the culture of violence that currently exists among inmates. The current formulation of the imminence requirement should remain in place, preventing actions that would ultimately damage the spirit and intent of the law. ${ }^{78}$

The Supreme Court has not addressed whether prisoners are a suspect class [for Equal Protection purposes]. The lower federal courts, however, have uniformly held that prisoners are a non-suspect group because status as a prisoner is not an immutable characteristic; entry into the class is voluntary; and entry into the class requires commission of an illegal act.

Jason E. Pepe, Challenging Congress's Latest Attempt to Confine Prisoners' Constitutional Rights, 23 HAMLINE L. REV. 59, 72 (1999) (footnote omitted); see Claire Oakes Finkelstein, On the Obligation of the State to Extend a Right of Self-Defense to its Citizens, 147 U. PA. L. REV. 1361, 1363 (1999) (suggesting that "even when the right to self-defense is conceived in its strongest form, it is not easily shown that the State is obliged to respect conduct in its exercise").

${ }^{75}$ See Robertson, supra note 1, at 343 ("The inmate subculture equates manliness and status with displays of 'toughness' and aggression."); see also Kaye, supra note 63, at 696 (noting that violence "improves the self-image of the user" within the prison).

${ }^{76}$ Robertson, supra note 1 , at 345 \& $\mathrm{n} .32$ ("A 'standup guy' is an inmate who is at the top of the prison caste system.... [T] his requires a willingness to use violence.").

${ }^{77} I d$. at 341 . Robertson uses this term to describe the subculture of violence and seeming lawlessness that exists behind prison walls.

${ }^{78}$ From a procedural standpoint, such a misappropriation of substantive selfdefense law would occur when criminal charges are brought against an inmate under federal or state law. See id. at 340 n.6 (noting the possibility of criminal charges). Prisoners are also subject to discipline within the prison through various internal rules governed by a given state's corrections department. See id. at 350-55 (describing various internal prison policies regarding self-defense). For the purposes of substantive law, the cases that are in the state or federal criminal system are more significant, due to their precedential value, however prison disciplinary boards often "apply the same standard used in the community" regarding substantive self-defense law. Id. at 353 (quotation marks omitted) (quoting a letter from J.C. Kenney, Assistant Director, Adult Institutions, Arizona Department of Corrections, to James E. Robertson (Jan. 4, 1995)). 


\section{B. The Prospective Effect on Prisons of Changes to the Imminence Requirement}

\section{Elimination of the Imminence Requirement}

The impact on prisons of eliminating the imminence requirement in self-defense cases is clear. Were the requirement eliminated, the unintentional effect would verge on official sanction of the predatory culture of prisoners attacking first.

If a necessity standard replaced the imminence requirement, prisoners who attack preemptively would be able to take advantage of the very nature of the necessity justification to exculpate themselves. The definition of necessity presupposes and labors to excuse a preemptive act: " $[t]$ he act charged must have been done to prevent a significant evil." ${ }^{79}$ Clearly, the first requirement of the necessity defense is advantageous to a defendant who commits a preemptive attack.

Likewise, the second requirement of necessity, that there must have been "no adequate alternative," aggressor to meet, thus excusing his actions. Such an attacker will argue that, in prison, backing down from even a verbal threat will brand him as weak, placing him in future danger. ${ }^{81}$ Additionally, prisoners will argue that protective custody in response to a threat is not feasible, as " $[\mathrm{m}]$ ost targets will refuse offers of protective custody because it . . . accords them 'non-men' status." If a prisoner is able to argue effectively that neither protective custody nor backing down to a threat is a legitimate alternative to self-help, a sympathetic jury may excuse a preemptive attack. This would set a dangerous precedent in an environment that already thrives on violence, as it would give prisoners yet another incentive to settle disputes through force.

A more difficult issue is the requirement of proportionality. ${ }^{83}$ An attacker hoping to use this excuse would have to show that the harm he caused was equal to or less than the harm threatened. ${ }^{84}$ The most

79 Nelson v. State, 597 P.2d 977, 979 (Alaska 1979) (emphasis added).

"Id. at 979 .

*1 See Robertson, supra note 1 , at 340 (quoting a prisoner on the importance of fighting as saying, "[a]s far as the inmate is concerned, you have to prove yourself to other inmates, as a man").

${ }^{82} I d$. at 344-45 (footnotes omitted).

${ }^{* 3}$ See Nelson, 597 P.2d at 979 (explaining that "the harm caused must not have been disproportionate to the harm avoided").

* See id. at 980 (finding disproportionality where the harm caused by self-defense 
likely way around this requirement for an inmate who wishes to use necessity as a defense is to point to the generally high levels of violence in prison, and state that a threatened violent or sexual attack was virtually certain to occur. ${ }^{85}$ At the same time, the attacker could point to past instances of violence to establish a baseline level of harm that he was trying to avoid. ${ }^{86}$ Proportionality is difficult to prove or disprove as there is usually little or no evidence available regarding theoretical future harm. The defendant is naturally in the best position to argue this point, as he can simply state what type of harm he feared, and the prosecution will have to use circumstantial evidence to disprove the defendant's state of mind. ${ }^{87}$

\section{Expansion of the Definition of Imminence}

The proposal to expand the definition of imminence to include situations involving a constant fear of harm is equally troublesome. ${ }^{88}$ Given the high levels of violence within prisons, an inmate who chooses to attack another inmate can simply argue that he was living in a constant state of fear. Thus, a threat of harm is always imminent under the proposed definition. ${ }^{89}$ If the threat of harm is always imminent, this proposal suggests that a preemptive strike could be excused regardless of how far removed the defensive act is from the actual threat. Because of the ubiquity of violence behind prison walls, an inmate defendant's argument that he was under a state of constant fear would certainly be plausible, notwithstanding the fact that an

was greater than the harm prevented).

Such an assertion will be effective particularly in jurisdictions that allow deadly force to prevent sexual assault. See supra note 6 and accompanying text (addressing the issue of proportionality between rape and homicide).

${ }^{86}$ This approach would be limited, however, by issues of relevance. See, e.g., State v. Wiggins, 808 P.2d 1383, 1386 (Kan. 1991) (upholding the trial court's determination that testimony regarding a prior self-defense killing at the Kansas State Penitentiary was irrelevant). This differs from battered woman syndrome cases in that a battered woman will have only her previous experiences to point to, while a prisoner may be able to point to instances of violence he has witnessed during his prison experience.

${ }^{87}$ See id. at 1385 ("Deadly force is justified when the defendant subjectively believes such force is necessary and is subject to an objective standard of reasonableness.").

${ }^{88}$ See supra Part II.B.2 (discussing this proposal as a reaction to battered woman syndrome cases).

${ }^{89}$ See, e.g., Robertson, supra note 1 , at 342 (noting that "the victimization of inmates by inmates is routine and expected and the corresponding fear of violence is indeed great" (footnote omitted)). Again, this Comment concedes that there are unquestionably high levels of violence within prisons, but seeks to address situations in which a prisoner can use that fact to his advantage to exculpate himself. 
attacker may have used violence, not out of fear, but to improve his status."

\section{Procedural Analysis and Availability of Alternatives}

The lack of alternatives to self-help in prison is also important when considering Rosen's proposed modification to self-defense law, which involves requiring a defendant to make a threshold showing that the attack was necessary despite a lack of imminence. ${ }^{91}$ A preemptive attacker will simply be able to argue that he had no reasonable alternative within the previously discussed prison subculture other than to attack another inmate without warning. Such a result, in a normative sense, is clearly undesirable because it encourages violent self-help that is not motivated by any colorable sense of justice. ${ }^{92}$

\section{Case Law Addressing Preemptive Self-Defense in Prison}

The substantive problems with expanding the definition of imminence to include states of constant fear (and by implication, eliminating the imminence requirement) are seen in some fairly recent case law addressing self-defense in prison. In State $v$. Wiggins, an inmate at the Kansas State Penitentiary claimed self-defense when he stabbed another inmate whom he suspected of theft." After reporting the theft to penitentiary officials, the defendant, Wiggins, was warned that "something would happen" both to him and to his cellmate the following morning. ${ }^{95}$ As a result, Wiggins chose to use a preemptive attack against the unarmed thief. At trial, Wiggins testified that "he knew he must [either] kill [the thief] or be killed himself." Additionally, a psychologist offered expert testimony on Wiggins's behalf regarding the "culture of fear" in prison, suggesting

See supra notes 75-76 and accompanying text (discussing the relationship between violence and stature in prisons).

"I Supra Part II.B.3. Rosen's failure to anticipate such uses of preemptive selfdefense is his theory's greatest weakness.

"2 Despite the lack of social value in preemptive strikes within prisons, there are situations where legitimate self-defense appears necessary in prison. Simply because an inmate should not be allowed to use a preemptive attack does not mean that the law must require him to "submit to his own destruction." Kaye, supra note 63 , at 722.

"808 P.2d 1383 (Kan. 1991).

See id. at 138485 (providing the factual background of the case).

"Is Id. at 1384.

*i: Id. at 1386. 
that Wiggins's actions were entirely reasonable given the circumstances. $^{97}$

Ultimately, Wiggins was convicted. If the jury had been presented with a definition of imminence that included "constant fear" of an attack, and thus excused a preemptive attack as an act of self-defense, however, it is not difficult to see how the outcome could have been different. ${ }^{98}$ Additionally, the defense's use of a respected psychologist's expert testimony would likely make a defendant's assertion that he was in constant fear more palatable and convincing to a jury, leading to a higher number of acquittals for preemptive attacks.

Such an expansion of the definition of imminence could have affected the outcome in United States $v$. Holt. ${ }^{100}$ In Holt, a prisoner convicted of inmate weapons possession claimed that he had procured the weapon in question for purposes of self-defense. ${ }^{101}$ The court concluded that:

Holt has failed to produce any evidence that he was under imminent threat of death or bodily injury when he possessed the knife.... Holt testified that he picked up the knife as his attackers fled the scene, and that he continued possessing the knife only because he was afraid they would return.... [H] owever, Holt's generalized fear of a repeat attack cannot qualify as an imminent threat of death or injury.

If the proposal to expand imminence to include continuous fear were accepted, Holt's generalized fear of a repeat attack would qualify as an imminent threat by definition.

Hence, Wiggins and Holt demonstrate the danger of expanding the definition of imminence. Inmates who live in an environment full

${ }^{97}$ Id. Although a self-defense instruction regarding reasonableness was the central issue considered by the Kansas Supreme Court in this case, issues of imminence and reasonableness are closely related. See supra notes 10-14 and accompanying text (describing the relationship between reasonableness and imminence).

${ }^{98}$ The jury was instructed, inter alia, that " [a] person is justified in the use of force against an aggressor when and to the extent ... that such conduct is necessary to defend himself ... against such aggressor's imminent use of unlawful force." Wiggins, 808 P.2d at 1385 (quoting jury instructions).

${ }^{99}$ See id. at 1386 (noting the expert testimony of Dr. Glen Lipson, a psychologist from the Menninger Foundation, who testified as to the value placed on violence in prisons).

${ }^{100} 79$ F.3d 14 (4th Cir. 1996).

${ }^{101}$ The court also discusses the propriety of raising a common law affirmative defense to a strict liability offense such as that at bar in this case. See id. at 16 (concluding that some courts have allowed the defense under certain circumstances). 
of violence will be able to state that they harbor a constant, generalized fear of attack. This fear, whether or not it attaches to a specific person, could qualify as an imminent threat of death or injury. In fact, the fear would not even need to be individualized towards specific aggressors, as is necessary with battered woman syndrome cases. ${ }^{103}$ In turn, this widening of the imminence requirement will qualify prisoners to claim self-defense when they preemptively attack another inmate or procure illegal weapons to ostensibly protect themselves. Proponents of changing the current substantive law of self-defense should realize that inmates may exploit the violent nature of prisons to their advantage, and that any possible change would, in the current substantive law of self-defense, have effects far beyond its intended purpose. The proponents' intention would be abused by the availability of the defense to those who have a fear of a specific aggressor, as is the case with a battered woman.

\section{THE CULTURAL DEFENSE AND THE POSSTBIITYY OF PREEMPTTVE SELF-DEFENSE}

Prison, however, is not the only context where a change in the imminence requirement could be misappropriated by an opportunistic defendant wishing to strike first. One of the more controversial recent developments in the arena of legal theory is the creation of the cultural defense. ${ }^{104}$ Proponents of the cultural defense argue that "[j] uries... decide whether cultural factors were determinative in a defendant's behavior, and, if so, whether that is sufficient to warrant either a lesser charge or complete acquittal." Cultural factors, according to certain commentators, are so behaviordeterminative that "evidence of culture [should be] introduced as

lis Generally, the self-defending inmate would be in fear of his ultimate attacker. See, e.g., Wiggins, 808 P.2d at $1384-85$ (noting that a particular inmate's fear of attack from another inmate arose out of a specific previous confrontation). However, it is conceivable that no previous confrontation is necessary in order to claim fearfulness, based on the very nature of prison itself. If violence is ubiquitous in prisons, it is likely that any given inmate has been involved in a violent confrontation at some point. An inmate, whether involved in the previous incident or not, could point to the other inmate's acts and reputation as legitimate sources of fear. See Kaye, supra note 63, at 696 (noting that the available evidence supports the idea of prison as a place where violence is ubiquitous); Robertson, supra note 1, at 343-45 (noting that an inmate's reputation of propensity for violence translates into status within the prison population).

\footnotetext{
See supra note 2 (discussing the theoretical bases of the cultural defense).

Renteln, supra note 2, at 440.
} 
relevant to show a lack of the requisite elements of the crime charged or to show a requisite element of a traditional defense, such as provocation or self-defense." 106 The cultural defense has proved successful in a handful of notorious cases through either acquittal or lessened charges. ${ }^{107}$

The reaction to the cultural defense is quite divided in the legal community. ${ }^{108}$ Although self-defense has not been an issue at the forefront of the debate over the cultural defense, the cultural defense has been used in conjunction with self-defense on certain occasions, with varying levels of success. ${ }^{109}$ Just because the cultural defense has not been widely used in connection with preemptive self-defense does not mean, however, that the possibility of future use is negligible. As has been shown in certain celebrated cases, attorneys can simply extend standard doctrine to fit even the most seemingly absurd legal theories. ${ }^{110}$ Given the typical defendant's instinct of self-preservation, it is not difficult to see that the cultural defense could be the next logical exploitation of any change in substantive self-defense law.

In cases where culture has been used as a part of a self-defense claim, reasonableness, rather than imminence, is typically the central issue. " In one case, People v. Croy, ${ }^{112}$ a Native American defendant's

${ }^{106}$ Deborah M. Boulette Taylor, Paying Attention to the Little Man Behind the Curtain: Destroying the Myth of the Liberal's Dilemma, 50 ME. L. REv. 446, 458 (1998).

${ }^{107}$ See Doriane Lambelet Coleman, Individualizing Justice Through Multiculturalism: The Liberals' Dilemma, 96 COLUM. L. REV. 1093, 1093-94 (describing some of these cases). Coleman describes the cultural defense as successful in the case of a JapaneseAmerican woman drowning her two children and subsequently claiming that she was engaging in the "time-honored, customary practice of parent-child suicide." Id. Also described is a case in which a Chinese-American man was acquitted of murder charges after he killed his wife for being unfaithful, claiming that his "conduct comports with a Chinese custom that allows husbands to dispel their shame in this way when their wives have been unfaithful." Id.

${ }^{108}$ Compare id. at 1166-67 (concluding that the cultural defense is undesirable because it would lead to "cultural codes" in which legal responsibility is based upon national origin), with Taylor, supra note 106 , at 470 (concluding that the cultural defense is consistent with the current state of the law).

${ }^{109}$ See Renteln, supra note 2, at 453-56 (discussing both successful and unsuccessful uses of the cultural defense).

110 Some of the more notorious examples of this phenomenon include the "Twinkie defense" raised by Don White in the murders of San Francisco Mayor George Moscone and Supervisor Harvey Milk, and the abused child defense raised by the Menendez brothers. See Morse, supra note 24, at 4 (arguing that these seemingly novel defenses are merely extensions of well settled legal doctrine).

"11 See Renteln, supra note 2, at 455 ("Any attempt to introduce cultural considerations via self-defense will require a 'subjective' interpretation of the reasonable person."). 
conviction for murdering a police officer was overturned after he argued that Native Americans were victims of discrimination and that they had been conditioned to distrust white authorities. ${ }^{113}$ Accordingly, Croy argued that "he was predisposed to perceive that his life was in jeopardy." 114 Croy prevailed on the theory that his actions were reasonable where he felt there was no opportunity for him to surrender to the officer. ${ }^{115}$

Yet, imminence has been at issue in certain cases involving the cultural defense. In $\mathrm{Ha}$ v. State, a Vietnamese immigrant argued that cultural considerations should lead to an instruction on self-defense, despite the lack of imminence. ${ }^{116}$ The facts of this case are not unlike a typical prison self-defense scenario. Ha got into a heated argument with another Vietnamese man who was working on the same ship. The man threatened $\mathrm{Ha}$, which led to an altercation between the two men. The next day, Ha shot the fellow employee in the back, killing him. ${ }^{117}$ During trial, in response to the judge's questions on the issue of imminence, Ha's lawyer responded that 'I think 'imminency' [is viewed through] the eyes of the person asserting justifiable force.... [The issue is] whether in [the] defendant's mind he felt that he was in imminent danger." 118 As a justification for this broad interpretation of imminence, Ha's lawyer argued that "[y]ou'd have to [ask] how would another Vietnamese, knowing how Vietnamese behave, knowing how, when Vietnamese make a public threat, that they carry it out and that you should take those threats seriously." 119 In essence, Ha was arguing for a cultural interpretation of the imminence requirement.

Ultimately, Ha was denied an instruction on self-defense, but the ramifications of an expanded definition of imminence (or an elimination of imminence) were made clear by this case. A primary obstacle to $\mathrm{Ha}$ obtaining a self-defense instruction was the imminence requirement, and the traditional definitions and legal notions that requirement carries. Were the imminence requirement to be given an expanded definition, or eliminated altogether (as suggested by

112710 P.2d 392 (Cal. 1985).

${ }^{113}$ See Renteln, supra note 2, at 454-55 (describing Croy's arguments on appeal and describing Croy's defense as a "culturally relative reasonable person test").

114 Id. at 454 .

${ }^{115}$ Id.

116. 892 P.2d 184 (Alaska Ct. App. 1995).

117 Id. at $186-87$.

${ }^{11 \times}$ Id. at $188-89$ (alterations in original).

119 Id. at 189 (second alteration in original). 
some commentators reacting to battered woman syndrome cases), similar preemptive strikes in the name of self-defense would become more commonplace and more likely to be excused by a jury. The prospective change in the imminence requirement would contribute to a legal atmosphere in which a defendant could scour his personal and cultural background for information that he could use in the courtroom, and the prospects of a jurisprudence that places value on acceptance of responsibility would be significantly dimmer. Ha's actions appear to be vigilantism rather than justice-whereas many would argue that justice is being served in the battered woman scenario-but Ha's actions run the risk of being legally sanctioned if the imminence requirement is changed to accommodate justice in the battered woman syndrome context.

Of particular interest is the fact that the imminence requirement for preemptive strikes by battered women was discussed by both the judge and defense counsel in the $H a$ case. ${ }^{120}$ Defense counsel argued that " $[t]$ he fact that [the victim] was shot from behind is irrelevant, just like the fact that a husband is shot while he's asleep." ${ }^{\text {,12 }}$ While denying a self-defense instruction on the basis of imminence, the judge addressed the issue of preemptive strikes by battered spouses, stating that:

Although in such instances there is commonly ample evidence to support a finding that the killing was motivated by fear and that the fear was as real and as urgent at the time of the killing as it was when the husband was awake and actually capable of immediate physical abuse, cases have uniformly refused to apply self-defense to this category of crime. The basis of the refusal has been lack of an immediate threat of harm. ${ }^{122}$

The significance of the judge's statement that "[t]he basis of refusal has been the lack of an immediate threat" lies in the recognition that a narrow imminence requirement is a barrier to a self-defense instruction for battered women. ${ }^{123}$ In the same vein, that narrow definition of imminence is the most significant barrier for an instruction in Ha's case. If, for example, the proposal to expand the definition of imminence to allow for constant fear was accepted in battered woman syndrome cases, Ha would be able to argue that due

120

Id. at $189-92$.

121 Id. at 189 (first alteration in original).

122 Id. at 191-92 (quoting Paul v. State, 655 P.2d 772, 778 n.8 (Alaska Ct. App. 1982)).

123 Id. at 192. 
to his Vietnamese culture, he was in constant fear of the man he killed and was therefore justified in killing him. ${ }^{124}$ Surely, this is not a desirable result, nor is it the intended result of commentators who argue that the imminence requirement should be modified in battered woman syndrome cases. ${ }^{125}$

Some obvious differences arise when the cultural defense is compared with battered woman cases and prison self-defense cases, most importantly, the availability of alternatives. ${ }^{126}$ From a theoretical standpoint, a case such as Ha's is quite different from one in which a defendant's back is truly against the wall. One who wished to use the cultural defense in such a manner, however, would be able to argue that "[he or she] was compelled to act the way he or she did" due to his or her culture. ${ }^{127}$ In such a case, proponents of the cultural defense argue, the individual's volition is psychologically dictated by her culture ${ }^{128}$ to the same extent that fear dictates the behavior of a battered woman or prisoner. As was previously addressed, the prospective effects of changing the substantive law are not limited to the area of battered women's cases, and an alternative is necessary. ${ }^{129}$

i24 See supra Part II.B.2 (describing the proposal to expand the definition of imminence to allow a particular defendant to argue that her constant fear based upon past experiences produces a perpetually imminent threat).

${ }^{125}$ One of the more difficult issues inherent in the cultural defense is the tension between respect for immigrant cultures and American notions of civil rights, especially as those rights apply to women. Doriane Coleman summarizes the cultural defense argument as mandating that, "in the name of cultural pluralism, a part of the law should take two steps back in this area of women's rights." Coleman, supra note 107, at 1142. Coleman also argues that "acceptance of these cultural norms forces immigrants, and most often immigrant women, to go back to a time when American law formally discriminated against women and people of color, a time to which most would agree we as a society do not want to return." Id.

12. Compare supra notes 38-40 and accompanying text (noting that battered women often do not believe that they can leave the abusive situation), with supra notes 74-76 and accompanying text (discussing the fact that a high value is placed on violence in prison, and that violence is important in gaining status).

${ }_{127}$ Renteln, supra note 2, at 439.

${ }^{12 \%}$ See id. (noting a lack of volition on the part of an individual whose behavior has been influenced largely by his culture).

${ }^{12}$ See supra text accompanying notes 32,48 (discussing the application of a change in the substantive law to areas outside of the limited realm of battered women's cases). For examples of cases that illustrate the point that preemptive self-defense might have been allowed if the substantive law were changed as proposed, see People $v$. Minifie, 920 P.2d 1337, 1343-46 (Cal. 1996) (involving a preemptive attack based on vague threats and fear of future harm), and State $v$. Buggs, 806 P.2d 1381, 1383-84 (Ariz. Ct. App. 1990) (involving a claim by a defendant that he shot a Crip gang member in preemptive self-defense based upon his fear of future gang violence). 


\section{AN ALtERnATIVE TO EXPANDING THE DEFINITION OF SELF-DEFENSE: EXECUTIVE CLEMENCY}

As changing the substantive law of self-defense will have negative, albeit unintentional, effects outside of the realm of battered women's cases, a different means to achieve the ends of justice is necessary. Advocating clemency in certain battered women's cases again presupposes some sort of moral justification for the act being excused. As has been noted, " $[w]$ hile there is no unanimous agreement that battered women who kill are, or should be, legally justified in their actions, one must admit that such women are in a different position with relation to justice than are other classes of homicide defendants." 130 Instead of changing substantive law in an attempt to achieve more acquittals at the trial level, advocates for battered women should consider alternative approaches, such as encouraging states to install a comprehensive system of clemency review to screen cases where battered women have been convicted of killing their abusers. Such an approach would ensure that a just result is reached, and would avoid the negative effects of changing the substantive definition of self-defense.

A majority of state constitutions vest the power of clemency exclusively in the state's executive. ${ }^{131}$ The concept of clemency encompasses various postconviction acts of relief:

A "pardon" is an executive action that mitigates or sets aside punishment for a crime; it is used most often to restore the reputation and civil rights of someone who has led an exemplary life subsequent to punishment. "Amnesty," which usually is granted to a group of people, in essence "overlooks" an offense because the conduct served to benefit the public good. "Commutation" substitutes a milder punishment for the one imposed; it does not remove the legal or moral guilt of the offender. ${ }^{132}$

In the context of clemency for battered women, commutation and pardons are the most common forms of postconviction relief.

Various theories for the granting of clemency have been put forth. First, clemency can provide relief in cases of "factual/legal innocence or substantial doubt of guilt." ${ }^{133}$ In such cases, the accused woman either did not commit the actus reus, or was legally justified in

${ }^{130}$ Christine Noelle Becker, Note, Clemency for Killers? Pardoning Battered Women Who Strike Back, 29 LOY. L.A. L. REv. 297, 312 (1995) (citation omitted).

${ }^{131}$ Joan H. Krause, Of Merciful Justice and Justified Mercy: Commuting the Sentences of Battered Women Who Kill, 46 FLA. L. REv. 699, 706 (1994).

${ }^{132}$ Id. (citations omitted).

${ }^{133}$ Becker, supra note 130 , at 325. 
committing the crime. ${ }^{134}$ Second, clemency may be available in cases involving "technical guilt with significant mitigating factors." ${ }^{135}$ This situation arises "when the defendant suffered from some sort of reduced ability at the time of the crime."136 Third, clemency can be used to address "technical guilt with moral innocence."137 Under a retributivist theory of justice, the woman who kills her battering spouse is free of moral guilt, and society would not benefit from seeking to punish her. ${ }^{138}$ A final ground for clemency involves "disparities in punishment and sentencing unrelated to deserts."139 This encompasses both "sentencing disparities among those convicted of the same crime within the same jurisdiction," and "sentencing that is unrelated to just deserts."

The use of the clemency power in battered woman syndrome cases, although currently not particularly widespread, is not necessarily novel. For example, in 1990, Ohio Governor Richard Celeste commuted the sentences of twenty-five women convicted of killing their abusive husbands. ${ }^{41}$ In this situation, the Ohio Adult Parole Board Authority ("APA") brought nineteen of well over one hundred case applications for clemency to the attention of the Governor, who then initiated proceedings himself for seven of those women. ${ }^{142}$ The women were able to present evidence on their own behalf during the reviews, and the Governor considered "medical records, prior convictions, the APA recommendations, and the inmates' prison records." 143 As a requirement for clemency, the governor required each of those who were to be released to have served at least two years in prison, and to perform an additional two hundred hours of community service. ${ }^{144}$ In 1991, Maryland Governor William Donald Schaefer also pardoned eight women who had been

\footnotetext{
${ }^{\mathrm{I} 34} \mathrm{Id}$.

1 Id. at 328.

1 isi $I$.

137 Id. at 329.
}

${ }^{138}$ See id. at 330 (noting also that "[o]ne additional situation where technical guilt with moral innocence is present is when the offender has already suffered enough to atone for their crime").

${ }^{134} \mathrm{Id}$.

${ }^{1411} I d$

${ }^{141}$ Krause, supra note 131, at 703.

142 See id. at 720-21 (describing Ohio's mechanism for initiating clemency proceedings).

Id. $I$. at 722 .

144 . at 723 . 
convicted, after meeting individually with these abused women. ${ }^{145}$ Finally, the defendant in the seminal case of Norman II was granted a commuted sentence two months after she entered prison. ${ }^{146}$

In order for clemency to be an effective alternative to legislative revision of self-defense, a coherent and predictable system of case review would be necessary. ${ }^{147}$ Often, cases of battered women who were convicted of killing their abusers are brought to the attention of a state governor by advocacy groups. ${ }^{148}$ In other situations, a governor will simply ask his aides to review the files of all convicted battered women to search for cases in which clemency might be appropriate. ${ }^{14 !}$ Such an approach, however, is criticized as lacking focus and being overinclusive. $^{150}$

One organized approach to reviewing battered women's cases was initiated in Texas, where the state parole board was encouraged to review "the cases of all persons who pled to or were convicted of murder or manslaughter when the offense was directly related to victimization by domestic violence." ${ }^{151}$ This more formal type of review that involves a state agency, rather than simply being initiated by advocacy groups or the governor, has the advantages of thoroughness and familiarity, as employees of a particular state parole board are better trained to screen cases that would be appropriate for clemency review. ${ }^{152}$ Under such a system, clemency need not be

${ }^{145}$ Id. at 727-28.

${ }^{146}$ DRESSLER, supra note 43 , at 445 (discussing Norman II, 378 S.E.2d at 8); see also supra note 3 (presuming most lay citizens would agree that Judy Norman's conviction should have been overturned).

${ }^{147}$ Such a formal system is necessary in part because of the "tendency among legislators to assume that once... a statute is enacted into law, the problem of battered women who kill their abusers has been fully addressed. Legislators often assume that once expert testimony on battered woman syndrome is statutorily allowed at trial, deserving victims will be acquitted." Becker, supra note 130, at 314 (citation omitted).

${ }^{148}$ See, e.g., Krause, supra note 131 , at 766 (noting that the commutations in Maryland were initiated through the work of advocacy groups).

${ }_{199}$ See, e.g., id. (noting this approach in Ohio).

${ }^{150}$ See id. at 765 (harboring these criticisms and asking, "[d]oes the governor review the case of every woman who could have presented evidence of abuse at trial? Does the governor review only those cases involving women who attempted to present the evidence but were not allowed to do so... [or] only the cases of those women whose files contain allegations of abuse?").

${ }^{151}$ Alison M. Madden, Note, Clemency for Battered Women Who Kill Their Abusers: Finding a Just Forum, 4 HASTINGS WOMEN'S L.J. 1, 79 (1993) (quotation marks omitted).

${ }^{152}$ See Krause, supra note 131, at 766-68 (discussing the qualifications of those who would review cases). 
limited to battered women's cases.

The granting of clemency to women who are convicted of killing their abusive husbands is not without its critics. The widespread use of clemency initiates serious separation of powers concerns, as an executive solution would essentially obviate the judiciary's traditional role in shaping the law of the land. ${ }^{153}$ Additionally, since the power of clemency is vested in the executive, it could become more of a political than legal tool. ${ }^{154}$ Likewise, there is a concern that if clemency becomes too common, battered woman syndrome will become an excuse at trial that can be used falsely to a defendant's advantage. $^{15}$ Additionally, there exists the possibility that battered woman syndrome would not be raised until after the trial, as a lastditch effort by a convicted defendant to clear her name using a tool designed to promote justice. While " $[\mathrm{i}] \mathrm{t}$ is possible in battering cases, just as in every other criminal case, that the accused may lie or exaggerate her position," a clemency reviewer would be in a strong position from an evidentiary standpoint to discern between legitimate and illegitimate claims. ${ }^{56}$

However, such a system will serve the interests of the law better than a modification of substantive self-defense law. Any negative effects will be limited to the context that the system is created to address, whereas a change in self-defense law would apply to all cases, not just those involving battered women. ${ }^{157}$ Clemency is preferable because it takes away the temptation for judges and legislators to modify the law to achieve a quick fix in a handful of cases. Instead, the better approach is to review cases after they have gone through the system to prevent unforeseen misappropriations of new common law precedent and statutory solutions. A system of clemency would also be preferable because, "[w] $w$ hile courts are limited in considering some types of evidence, a governor is not bound by these rules."15s Overly formalistic rules of evidence may exclude many relevant facts at

See id. at 724 (discussing concerns among prosecutors that clemency infringes a jury's authority).

${ }_{1: 4}$ See, e.g., Linda L. Ammons, Discretionary Justice: A Legal and Policy Analysis of a Governor's Use of the Clemency Power in the Cases of Incarcerated Battered Women, 3 J.L. \& POL'Y 1, 48-51 (1994) (giving examples of "partisan pardons").

See id. at 57 (noting the concern that a battered woman syndrome defense might be fabricated).

ID. at 58 .

157 See supra Parts III, IV (discussing the application of precedent in other situations).

IT. Ammons, supra note 154 , at 76. 
trial, facts that a clemency reviewer would be able to consider in reaching a fully informed decision. Likewise, "[a] governor's definition of justice can be broader than just what the law requires and under such circumstance she could use her power of clemency to reflect a justice as fairness stance. ${ }^{159}$ Finally, unlike common law interpretations of self-defense, which vary from state to state, " $[t]$ he law on clemency is settled. Regardless of the reasons an executive may have for granting clemency, the scrutiny of this discretionary act will be left to the political process rather than to the courts." 160 It is for these reasons of limited reach and the potential for more fact specific inquiries that a post-conviction system of relief through clemency is preferable to ill-conceived alterations in self-defense law. While not a perfect or exclusive solution, it is a more acceptable means to achieve justice in battered women's cases than modifying the pre-existing law of self-defense.

\section{CONCLUSION}

Violence is never a desirable result to a conflict. The law of selfdefense recognizes, however, that violence is sometimes necessary and justified to defend oneself from an imminent attack. In cases involving battered women, the substantive law often precludes a jury instruction on self-defense because the act of self-defense was so far removed from any imminent harm that the act does not fit the definition that the law provides. While some would argue that battered women are morally justified in using a preemptive strike as a means of self-defense, those who believe that a change in the law is necessary to protect battered women do not recognize the prospective effects of such a change. A relaxed imminence requirement could be misappropriated by prisoners, and through the cultural defense, used to allow preemptive self-defense in cases in which society is less prepared to accept it as a legitimate use of self-help. As a result, proponents of changing self-defense law as a reaction to battered women's cases should instead focus their efforts on encouraging a formal clemency review system to achieve their goals without negative prospective effects. 